\title{
PAULO LEMINSKI: UM POETA LONGE DEMAIS DA(O)S CAPITAIS
}

Lívia Mendes PEREIRA ${ }^{1}$

Paulo Leminski, poeta curitibano, vivia "longe demais das capitais"2, assim como cantou seu vizinho sulista, Humberto Gessinger, e foi, por muito tempo, rotulado um poeta "marginal", não apenas por estar à margem da região mais rica e produtiva do país, mas também por acreditar que a poesia bastava por si mesma, qualificada pelo poeta um "inutensílio", pois este acreditava que a poesia era uma força contra a mistificação literária ${ }^{3}$.

Muitas pessoas acreditam que, ironicamente, a poesia de Leminski tenha se voltado contra os ideais do próprio poeta na ocasião da publicação, pela editora Companhia das Letras, de seus poemas, no volume denominado Toda Poesia, no ano de $2013^{4}$, já que a obra alcançou record de vendas e ficou por muitas semanas no topo das listas dos mais vendidos. 0 espanto não é de se estranhar, pois um livro de poesia estar entre os mais vendidos no Brasil, um país em que a leitura atinge uma parcela pequena da população e que, na maioria das vezes, essa parcela de leitores preferem leituras de fácil acesso, por exemplo os livros de auto-ajuda ou as traduções facilitadas dos best-sellers norte-americanos, é realmente inusitado.

\footnotetext{
${ }^{1}$ Mestranda em Estudos Literários. Faculdade de Ciências e Letras de Araraquara - UNESP. E-mail: ligessinger@gmail.com

${ }^{2}$ GESSINGER, H. Longe demais das Capitais. In: Engenheiros do Hawaii. Longe demais das Capitais. Porto Alegre: BMG, 1986. 1 CD.

3 "Quem quer que a poesia sirva para alguma coisa não ama a poesia. Ama outra coisa. Afinal, a arte só tem alcance prático em suas manifestações inferiores, na diluição da informação original. Os que exigem conteúdos querem que a poesia produza um lucro ideológico" (LEMINSKI, P. Ensaios e Anseios crípticos. Campinas: Editora Unicamp, 2011. p.86-87).
}

${ }^{4}$ LEMINSKI, P. Toda Poesia. São Paulo: Companhia das Letras, 2013. 
Diante desse milagre, muitos acabam acreditando e afirmando que o motivo de tamanho sucesso esteja na facilidade ou na falta de rebuscamento das poesias de Paulo Leminski e que talvez isso se devesse à influência dos compartilhamentos dessa "poesia de fácil acesso" nas redes sociais, se nos fiarmos no que insinuou Luis Dolhnikoff em sua resenha "Paulo Leminski, O Paulo Coelho da

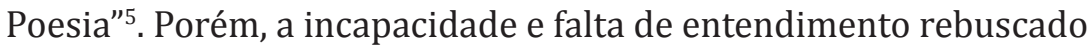
não está no poeta, mas no próprio crítico-leitor. Como o próprio cachorro louco afirmava a poesia é feita para poetas, e esse poeta não é somente quem escreve poesia, mas também alguém que possui capacidade e sensibilidade para entendê-la ${ }^{6}$. Dessa forma, é totalmente ingênuo afirmar que Leminski hesitava entre o "capricho" e o "relaxo", apropriando-se do nome de uma de suas obras de forma errônea e equivocada, pois o "relaxo" que o poeta insere em seus poemas e indica em seu título, não se trata de um descuido qualquer, mas da essência de sua poesia, que se firma em não negar as características formais e complexas da arte, porém, por outro lado, não deixa de ser acessível ao grande público. 0 verdadeiro "relaxo", no sentido depreciativo do termo, está no mero leitor que não consegue ler Leminski além da superfície.

Ao se deparar com esse poema, da seção "Ideolágrimas" de Caprichos \& Relaxos

$$
\begin{aligned}
& \text { a palmeira estremece } \\
& \text { palmas pra ela } \\
& \text { que ela merece (p.114) }
\end{aligned}
$$

O leitor distraído das redes sociais pode ter a impressão de um poema infantil, bonito, musical. Um leitor "relaxado", no sentido ruim da palavra, pode entender que a poesia não diz absolutamente nada e só tem importância para ser compartilhada ao lado de um

\footnotetext{
5 Disponível em: <http://www.digestivocultural.com/colunistas/coluna.

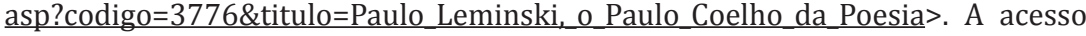
em 13/06/2013.
}

6 "Tem que ter tanta poesia no receptor quanto no emissor" (idem, p.133) 
desenho ou de uma foto, para provocar um sorriso em um amigo. Porém, um leitor "poeta", assim denominado por Leminski, entende a intenção lúdica e alusiva, a musicalidade no uso da paronomásia, o diálogo com o gênero haicai e procura, na própria sugestão do poeta em seu prefácio, entender o poema em seu contexto e sua intenção.

Aqui, poemas para lerem, em silêncio,

O olho, o coração e a inteligência.

Poemas para dizer, em voz alta.

Poemas, letras, lyrics, para cantar.

Quais, quais, é com você, parceiro. (p.27)

Portanto, Paulo Leminski não negava que a poesia poderia ser acessível, mas repudiava a poesia ou a literatura que possuía apenas esse objetivo rentável, para o poeta a matéria da poesia, que é a palavra, é essencialmente política e ética e, por isso mesmo, não pode ser transformada em simples mercadoria.

Os textos feitos para vender, que assumem o topo do ranking não podem ser comparados à poesia pura e simples do poeta curitibano, em que a literatura apenas funciona como literatura, em seu estado natural. Se parece uma poesia de fácil acesso para o leitor da superfície, é nesse engano propositalmente instaurado que mora a sua genialidade, a capacidade de construir inúmeras camadas a serem desvendadas e deixá-las à disposição do mais fino leitor, para que ele desvende seus próprios caminhos. Por isso, sua obra se aproxima dos grandes meios de comunicação, da publicidade, da canção popular, da poesia beat, tudo isso para incorporá-la a todo tipo de público e articulá-la com efeitos como o riso, o susto e o inesperado.

Toda Poesia reúne a totalidade de versos de Leminski já publicados em livros, desde o primeiro Quarenta clics em Curitiba (1976) até o póstumo Winterverno (2001) e fecha a parte dedicada à poesia com a seção "Poemas esparsos", que reúne os poemas que nunca apareceram nas obras anteriores. 0 livro inicia com 
a apresentação de Alice Ruiz, ex-esposa do poeta, que conta a trajetória íntima que teve com Leminski e com a edição de seus livros tanto em vida como depois de sua morte. A edição também conta com posfácio de José Miguel Wisnik, crítico e compositor, intitulado "nota sobre Leminski cancionista", em que ele analisa a forma e as características das canções do poeta, comentando também a relação de suas parcerias com outros músicos, inclusive com o próprio Wisnik. A antologia termina com um apêndice, em que são apresentados os textos de críticos literários e amigos de Leminski, publicados anteriormente em outras edições, com comentários a respeito da vida do poeta e também sobre sua poesia. A edição teve capa e projeto gráfico de Elisa von Randow, que escolheu a característica mais marcante de Leminski, o bigode, para ilustrar a capa de sua antologia. Todo o livro traz editoração e disposição dos poemas coincidentes aos originais, apenas são modificados aqueles livros que foram publicados originalmente em conjunto com fotografias e desenhos. Se comparado com os originais, o livro é bem completo e bem organizado, talvez o que mais fez falta são os projetos gráficos de fotografia e desenhos que ficaram de fora da antologia, o que dá um ar de incompletude aos poemas dos livros que foram editados juntamente com fotógrafos e artistas plásticos em seu original. Sente-se falta também de dois textos de Arnaldo Antunes, amigo e parceiro de Leminski, um sobre o livro Winterverno e outro escrito na ocasião de aniversário de 10 anos da morte do poeta, ambos publicados em 40 escritos $^{7}$. Vale lembrar ainda que o livro ganhou, no ano de seu lançamento, o Grande Prêmio da Crítica da APCA (Associação Paulista de Críticos de Artes), na categoria Literatura.

Diferente do que diz a visão errônea daqueles que criticam o sucesso da antologia póstuma de Paulo Leminski, o êxito de Toda Poesia (2013) foi totalmente coerente com o projeto poético e com o que foi anunciado pelo autor durante toda sua vida. Paulo Leminski conseguiu, efetivamente, como lembra Solange Yokozawa, no

${ }^{7}$ ANTUNES, A. 40 escritos. Iluminuras: São Paulo, 2000. 
artigo "Poesia e leitor na contemporaneidade: a (re)visão de Paulo

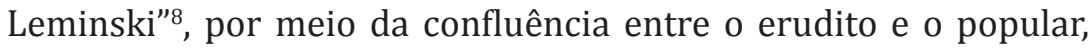
criar obras muito múltiplas e atingir públicos completamente diversos, mantendo-se vivo em seus poemas e em sua arte. Dessa forma, o poeta acabou por provar que, em sua essência, mesmo face à lógica do "capital”, ainda assim esteve e estará longe demais dos "Capitais".

${ }^{8}$ YOKOZAWA, S. F. C. Poesia e leitor na contemporaneidade: a (re)visão de Paulo Leminski. In: CAMARGO, F. P.; VIEIRA, M. M. C.; FONSECA, V. N. da S. (Org.). Olhares críticos sobre literatura e ensino. São Paulo: Fonte, 2014, v. 1, p. 33-52. 
238 Revista Texto Poético | ISSN: 1808-5385 | Vol. 16 (1ºm-2014) | p. 233-238 